\title{
RESENHA
}

\section{PEDAGOGIA DO COMPROMISSO: AMÉRICA LATINA E EDUCAÇÃO POPULAR}

\author{
Arthur Breno Stürmer ${ }^{1}$
}

A obra Pedagogia do Compromisso: América Latina e Educação Popular foi publicada pela primeira vez há treze anos (2008), em meio a debates efervescentes sobre a educação popular no Brasil, quando da ascensão de governos populares na América Latina. Paulo Freire foi posto em evidência, qual intérprete dos problemas nacionais e regionais, a partir de uma visão anticolonialista e a favor da libertação dos povos oprimidos. Via-se nele, também, o legítimo representante do pensamento brasileiro - e mundial - em educação popular e educação de jovens e adultos.

A primeira publicação desta obra foi no ano anterior à realização do Fórum Mundial de Educação Profissional e Tecnológica (23 a 27/11/2009), em Brasília-DF, durante o qual se declarou anistia ao educador pela Comissão de Anistia do Ministério da Justiça. Comemoravam-se os 100 anos da Rede Federal e a implantação dos Institutos Federais de Educação Profissional, Científica e Tecnológica, que viriam ofertar educação profissional e tecnológica a Jovens e Adultos inspirando-se em Paulo Freire.

Sua potência teórica, somada à força militante, mereceu ser incluída na Coleção Educadores, de 2010, publicada pelo Ministério da Educação, em parceria com a UNESCO e Fundação Joaquim Nabuco. Entretanto, o reconhecimento da importância do singular método de alfabetização de adultos e de toda a obra, escrita e vivida, culminou, em 2012, com o reconhecimento máximo que um povo devia ao seu maior expoente no campo educacional e pedagógico: o título de Patrono da Educação Brasileira.

A partir do golpe político-jurídico-midiático e do impeachment em 2016, o Brasil passou a conviver com a austeridade financeira também no campo da educação pública e com a elevação do desapreço em relação à educação popular, por parte de alguns grupos. Tal fato marcou o antes e o depois das eleições presidenciais de outubro de 2018 em meio a um

\footnotetext{
${ }^{1}$ Doutor em Geografia, Mestre em Desenvolvimento Regional e Meio Ambiente, Especialista em Docência na Educação Básica e Especialista em Gestão Educacional, é docente do Instituto Federal de Alagoas - IFAL com experiência na Educação de Jovens e Adultos e Educação Popular. Orcid: http://orcid.org/0000-0002-0510-8454 E-mail: arthur.sturmer@ifal.edu.br.
}

Revista de Estudos em Educação e Diversidade. v. 2, n. 5, p. 1-6, jul./set. 2021.

Disponível em: http://periodicos2.uesb.br/index.php/reed

ISSN: 2675-6889 


\section{Revista de Estudos em Educação e Diversidade}

REED

conjunto de temas que vieram palmilhando o golpe, como o "kit gay" nas escolas, a "ideologia de gênero" no Plano Nacional de Educação (PNE), a política de cotas no ensino superior, o homeschooling e outros.

O "compromisso", próprio da educação libertadora, passara, igualmente, a entrar na pauta negativa da extrema direita brasileira, que vê em Paulo Freire e seu legado histórico um alvo. A campanha difamatória ${ }^{2}$, porém, teve como resposta imediata do público a intensificação da procura pelas suas obras "clássicas", motivando a redescoberta de Freire.

Este é o contexto histórico da publicação de Pedagogia do Compromisso, que traz textos inéditos, com a apresentação e organização de Ana Maria Araújo Freire, a Nita, trazendo à tona escritos e registros temporalmente ligados ao retorno do autor ao Brasil depois do exílio. O país vinha passando pelo processo de redemocratização e de inserção forçada, nos limiares do século XX, na economia globalizada, quando as políticas neoliberais incidiam sobre os mais diversos setores da sociedade, cultura e educação. A obra não se construiu alheia, portanto, ao momento histórico e à práxis do autor. Pelo contrário, é justamente essa coerência que Ana Maria Freire resgata com maestria, tornando-a uma coletânea empolgante de textos com caráter político e militante em favor da educação popular, mas não só isso. A coloquialidade vinda de discursos, seminários, entrevistas e debates é o ponto forte de um aspecto formal a lembrar da defesa inegociável do diálogo na educação. Tal disposição aqui vem combinada à rigorosidade metódica, à afetividade e a um profundo amor pelo Brasil e seu povo, coisas comuns aos intelectuais que levaram para o exílio um sentimento hoje raro nas figuras públicas.

Essas marcas são atributos indissociáveis do autor desde sua obra-prima, Pedagogia do Oprimido, a qual revela a consciência acerca dos problemas nacionais e do papel da educação numa perspectiva libertadora, avessa ao autoritarismo entre os sujeitos da relação pedagógica e às imposições culturais. Em outras palavras, o autor advoga a problematização da realidade vivenciada pelo educando, o que implica este ter voz, pronunciar a sua palavra, recuperar sua humanidade, superar a consciência ingênua e ir para a luta, buscar mudanças.

O grande diferencial de Pedagogia do Compromisso reside em dois pontos principais. $\mathrm{O}$ primeiro deles é trazer à atualidade textos de vinte, trinta anos atrás que ainda servem à reflexão e compreensão de problemas não resolvidos no Brasil e na América Latina: a

\footnotetext{
${ }^{2}$ Os ataques à dignidade do Patrono da Educação Brasileira resultaram, em 16 de setembro de 2021, na liminar da Justiça Federal do Rio de Janeiro determinando à União que "abstenha-se de praticar qualquer ato atentatório à dignidade do professor Paulo Freire na condição de Patrono da Educação Brasileira".
}

Revista de Estudos em Educação e Diversidade. v. 2, n. 5, p. 1-6, jul./set. 2021.

Disponível em: http://periodicos2.uesb.br/index.php/reed

ISSN: 2675-6889 


\section{Revista de Estudos em Educação e Diversidade}

REED

democracia, a cidadania, a tolerância e o respeito à diferença. Em suma, problemas comuns entre as nações latino-americanas, cujos laços históricos, políticos e culturais carecem de reconhecimento para fortalecer a solidariedade, cumplicidade e apreço entre elas.

O segundo ponto relevante é que os textos desta obra reforçam a universalidade da teoria educacional de Paulo Freire, a qual ganhou a América Latina e o mundo, exigindo dele andanças que the renderam o epíteto de "andarilho da utopia". Embora a Pedagogia do Compromisso tenha destacado a reflexão sobre questões atinentes à Argentina, Brasil, Chile, Nicarágua, Paraguai e Uruguai, em todos os textos percebe-se a abrangência dos temas abordados por Paulo Freire.

Comparece, desde o início da obra, a luta permanente pela liberdade - dentro de uma pedagogia libertadora ou de uma educação como prática da liberdade -, abordando a educação na sua interface com a política. Diante da crise da educação, que é a crise da sociedade - afirma -, "a confrontação não é pedagógica e sim política" (FREIRE, 2018, p. $56)^{3}$, com educadores pressionando os políticos.

Há outras lições importantes de Freire nesta obra de valor tanto educacional e pedagógico quanto histórico. Muitas vêm lá dos idos dos anos 1990, mas que não podem ser datadas ou consideradas ultrapassadas, visto que seu conteúdo se atualiza constantemente, mesmo hoje, nos tempos de pandemia. Se falarmos de fake news, encontraremos referências à tarefa dos educadores na transformação da comunicabilidade em comunicação; se for o caso de nos depararmos com o negacionismo, autoritarismo e desesperança, a orientação é de não se dobrar à "ideologia paralisante e fatalista que o discurso neoliberal tem imposto" (FREIRE, 2018, p. 57). Nas palavras de Freire: “a realidade não é assim, a realidade está sendo assim" (ibid., p. 58). Quer dizer, sempre há uma saída que, intuímos, passa pela educação e pelo fazer do educador.

Muitas outras lições deixam claros os posicionamentos freirianos em prol da mudança e da transformação: "o conteúdo, sozinho, não explica as coisas. Inclusive a transformação. [...] eu não posso ficar apenas no nível do conteúdo, porque devo ultrapassá-lo." (FREIRE, 2018, ibid., p. 80-81). Isso porque, de acordo com Paulo Freire, "a educação é uma prática eminentemente política" (ibid., p. 56). Ele nos ajuda, também, a ficar alertas para enfrentar os fantasmas do passado (tecnicismo pedagógico, mentalidade burocrática) e os do presente (a racionalidade instrumental, o primado da técnica e das tecnologias "aplicadas" à educação):

\footnotetext{
${ }^{3}$ As citações diretas com indicação de página referem-se aos textos de Paulo Freire, que compõe a obra objeto desta resenha.
}

Revista de Estudos em Educação e Diversidade. v. 2, n. 5, p. 1-6, jul./set. 2021.

Disponível em: http://periodicos2.uesb.br/index.php/reed

ISSN: 2675-6889 


\section{Revista de Estudos em Educação e Diversidade}

REED

"somos gente antes de sermos especialistas" (ibid., p. 58); e a corrigir as práticas bancárias no ensino: "ensinar já não é [...] a transferência bem-feita [...]. Ensinar é, sobretudo, desafiar o aluno para que o aluno saiba o que o professor já sabe" (ibid., p. 70).

Em cada seção de Pedagogia do Compromisso o leitor irá reencontrar o autor de Pedagogia do Oprimido, de Professora, sim; tia, não, de Pedagogia da Autonomia e tantas outras célebres obras que sintetizam o pensamento freiriano. Continuam com a mesma coerência, militância e presença humana, sensível e atenta, transpirando o educador que Paulo Freire foi em vida. Ao folhear as páginas de Pedagogia do Compromisso, lê-se o teórico e o prático, o acadêmico e o pedagogo. Dá-se a palavra àquele que tão bem mostrou a importância de se dizer a palavra - palavramundo. O mesmo Freire, aqui, diz a palavra e a traduz em ação, exemplifica com situações concretas e se abre às diferentes realidades. Pratica seu método dialógico: diz, escuta, fala, permitindo uma leitura-diálogo acompanhada do compromisso. Nota-se nas falas a preocupação em ensinar a teoria, ouvir o outro e conferir se o "aluno" aprendeu. É a verdadeira comunicação, encontro de sujeitos, uma comunhão para libertar-se, educação mediatizada pelo mundo.

A palavra sedimentada no papel "chama" o leitor; parece aproximá-lo de sua própria realidade - uma escuta. Percebe-se a força, o vigor e a crença no diálogo ao modo socrático, que Freire ilustra com frases fortes e carregadas de sentido, já conhecidas do grande público, mas que aos neófitos da seara educacional parecerão simples recursos estilísticos. Pois que seja, dado que são marcantes e pontuam falas impregnadas do contexto histórico no qual foram gestadas e pronunciadas. Aliás, a história não escapa a nenhum grande pensador. Este esgarça os fios da história latino-americana na maior parte dos textos, mostrando o poder interpretativo de suas teorias e a perenidade das suas reflexões.

E para que vale a pena ler e reler Paulo Freire? Ele mesmo responde indignado: porque os problemas que nos desafiam hoje permanecem os mesmos. O principal deles podemos aqui confirmar - são as imposições das políticas neoliberais que, em pleno século XXI, descambaram para o antidiálogo, o autoritarismo e a antidemocracia. Coisas que o autor de Ação cultural para a liberdade talvez jamais tenha imaginado retornassem um dia, especialmente como epidemia no Brasil. Quem falou e lutou pela mudança de uma sociedade fechada para uma sociedade aberta; que sonhou com um país democrático; que queria ver a libertação do oprimido, e que para isso semeou a esperança e esperançou os educadores; que deixou legados às secretarias de educação Brasil afora; que foi eleito o Patrono da Educação Brasileira no ano de 2012... Esse Paulo Freire está bem representado na obra Pedagogia do

Revista de Estudos em Educação e Diversidade. v. 2, n. 5, p. 1-6, jul./set. 2021.

Disponível em: http://periodicos2.uesb.br/index.php/reed

ISSN: 2675-6889 


\section{Revista de Estudos em Educação e Diversidade}

REED

Compromisso, que, se cumpre um papel entre nós, é o de resgatar o gosto pelo pensamento crítico na educação, avivar a consciência de classe dos educadores e mostrar que há utopias realizáveis, isto é, sonhar é preciso, possível e necessário diante das inúmeras fatalidades e fatalismos correntes no cenário nacional e internacional.

Pedagogia do Compromisso, como literatura educacional, é como qualquer livro de Paulo Freire; como registro histórico, então, é formidável, porém, como convite à reflexão, é simplesmente o puxão de orelha ao se chocar contra seu oposto: o descompromisso com a educação popular, senão negligência e desmonte desta em face do avanço das políticas neoliberais, com destaque aos recentes "movimentos" contra a educação, contra a política da educação; a negação da docência, da ciência e do saber popular e da ancestralidade; em face das diversas "mordaças", da quebra da autonomia universitária e das ânsias privatistas, mascaradas, a pretexto de "futurar" as instituições de educação pública.

Se há obras que iluminam caminhos, essa é uma delas. Apesar de todas as dificuldades da educação popular no Brasil - com o desinvestimento e a descontinuidade dos programas voltados à educação popular -, os escritos de Freire apontam para a valorização da cultura popular, a superação dos preconceitos de classe e a conscientização que habilita os educadores para o enfrentamento.

É de pedagogia e compromisso que a presente obra se enche, abundante de ideias inspiradoras para novos tempos a partir de soluções relativamente conhecidas, como a primazia da competência - "se ensina, tem de ser competente" (FREIRE, 2018, p. 72) -, do como se entende o ato de ensinar e de como se ensina. Não falta a ênfase quanto à relação pedagógica em que o papel do estudante é o do sujeito ativo, que busca, que é curioso. Já o papel do professor - democrático nesta relação -, deixa de ser o transmissor de conteúdos e vem a ser o provocador da curiosidade no educando; aquela curiosidade que o levará a assumir a postura de quem quer conhecer o objeto que está sendo ensinado. Ruben Alves o chamaria de Professor de Espantos ou aquele que é capaz de provocar a curiosidade própria do ato de conhecer. Freire entendeu-o como o provocador de um ato de conhecimento que conduz a apoderar-se do objeto. Atualmente, tais ideias, por si, são antídotos à deslegitimação da docência, posto que colocam os educadores e educadoras como profissionais aos quais cabe ser ativos sem ser repressores, abertos sem ser licenciosos, enfim, afetivos e amorosos sem ser "tio" e "tia".

Pedagogia do Compromisso consegue, por fim, impregnar-se da responsabilidade que não pode faltar ao educador e gestor educacional. O título remete mesmo àquilo que pode

Revista de Estudos em Educação e Diversidade. v. 2, n. 5, p. 1-6, jul./set. 2021.

Disponível em: http://periodicos2.uesb.br/index.php/reed

ISSN: 2675-6889 


\section{Revista de Estudos em Educação e Diversidade}

REED

estar faltando aos governantes de veste neoliberal conservadora (!) quando evitam os grandes problemas da educação brasileira (e latino-americana) - ainda por serem resolvidos.

Em síntese, Pedagogia do Compromisso tem características de uma obra compilatória de textos situados no tempo e no espaço, embora seu valor atravesse datas e épocas. Constituise em registro histórico da práxis freiriana, manual de aplicação de sua teoria, guia introdutório aos problemas educacionais gerais segundo a ótica libertadora ou, conforme o nível de compreensão do leitor, um relato de andanças pedagógicas pela América Latina, que resgata categorias fundamentais do pensamento de Paulo Freire vindos de suas obras mais conhecidas.

Por fim, à indagação: “- Que compromisso é esse que funda uma pedagogia?”, a resposta é simples: Freire guarda um compromisso primeiro com a humanização do homem e das relações humanas, que se ergue e brota a cada página à semelhança de ferramenta ética que mune o educador para o enfrentamento do desmonte da educação popular via políticas de governo empapadas da ideologia neoliberal. O compromisso é um chamado para a luta contra a desumanização provocada pelo inimigo comum ao povo latino. Sem falsa neutralidade, a educação freiriana é política e, neste campo, o "compromisso" é contra a desobrigação do Estado neoliberal com a educação pública e os processos de mudança e transformação da sociedade. Outra resposta no domínio do como se leva a cabo este compromisso(s) é: matando a ideologia "ideologicamente", combatendo o fatalismo, imobilismo e desesperança com uma pedagogia de compromisso real, concreto, solidário e engajado na humanização do homem.

\section{Referência}

FREIRE, Paulo. Pedagogia do Compromisso: América Latina e Educação Popular. Organização e notas de Ana Maria Araújo Freire. 1. ed. Rio de Janeiro; São Paulo: Paz e Terra, 2018.

Recebido em: 04 de agosto de 2021.

Aprovado em: 23 de setembro de 2021.

Revista de Estudos em Educação e Diversidade. v. 2, n. 5, p. 1-6, jul./set. 2021. 